\title{
Poetry of Ghanaian Hip-Life Music: Reflections on the Thematology of Selected Hip-Life Songs
}

\author{
Felicia Annin \\ Department of General Education, Valley View University, Accra Ghana
}

\begin{abstract}
It is always important that society has an idea of the direction of its creative expression and this study is meant to fill a vacuum as it is intended to supply new information on this trend of Hip-life music. This paper explores the relevance of Hip-life music in the context of poetry. The significance of the study lies in the fact that it is a whole new way of life and being the dominant literary mouthpiece of the youth of Ghana, it is at least necessary to listen to what they are saying and why they are firing so. Again the departure from the grand themes of Highlife, which is at the base of Hip-life, to the banal themes of daily existence that have been a dominant feature of the twentieth century is so marked and so significant that it is worth studying. Such a study is expected to provide answers to such questions as: What gave rise to such a dramatic change or development? What is the new direction?

Different methods were employed in collecting data on the songs. With the data collection, a face-toface interview method was used to collate data on the evolution and future of Hip-life music from artistes, composers and studio engineers. The collection of the songs was two folds: transcription of the songs and some written songs at the cover of the albums. It concludes by summarizing the various themes analyzed and gives suggestion as to the future of Hip-life music.
\end{abstract}

Key Words: Hip-life, poetry, culture, highlife, thematology.

\section{Introduction}

Several African writers have written extensively on culture since it the way of life of people living in a society. The relevance of songs in our culture has compelled some of these writers to incorporate songs in their piece of writing so as to arouse the interest of the audience and also to portray our culture. Among such is Ola Rotimi who in his play, The Gods are not to Blame (1971) introduces the Townpeople who sing dirges and other songs. In the same vein, Efua T. Sutherland also uses 'mboguo' (songs) in her play, The Marriage of Anansewaa (1975). Soyinka also introduces the village girls who sing in his play The Lion and the Jewel (1963).

Ghanaian culture includes songs, and these songs are part of our daily lives. Like all other foIk songs, they must be studied in the broader content of culture. This is because the meaning of a song can be derived from the world view of those who create, perform and listen to it and from the function of the song in that culture. Hence, there must be a relation between the verbal content of the songs and other areas of culture. In Ghana, there are songs for nearly every occasion or circumstances, including ceremonial and work songs, occupational songs, contest and victory songs sung by athletes, gospel music, highlife music and, currently, hiplife music.

Ghanaians value the essence of the words in songs and this is highlighted and revealed by Turkson (1973). He stressed that the texts of the songs have emotional impact on the life of people:

Going along with abstractibility and non abstractibility of music from the

contextualorganisation is the use of text. The text is the most important

factor in the determination of emotional effect of the music sound. The Ghanaian

listens to the text of the song rather than the music sound. The song-text may be said to induce emotions in the Ghanaian. He considers the message of the text in judging his own life. In other words, he sees his image in the message conveyed by the text. Thus, song-text is a functional aesthetic which is found widely among Ghanaians and indeed African as a whole. Ghanaians look first for what is contained in the song text to fulfil their inward satisfaction... (Turkson, 1973)

It is therefore expedient for us to know the lyrics contained in most hip-life songs because language is an important instrument in African music. The history of hip-life or rap as a part of lifestyle cannot be separated from the coming of the European and the colonization of Ghana (Africa).

Hip-life is a term that does not yield itself to easy definition. This is because, is not just music; it is a combination of music, body expression and manner of expression. At the musical level, Hip-life is a derivation from Highlife, Hip-hop and Rap. Hip-life music was coined with the aim of familiarizing the people 
of Ghana with Hip-hop which was then the choice of the masses. In other words, it intended to use the local dialect to break the barriers for the youth that were into Hip-hop but could not understand English. In an interview with the World Hip Hop Bible, the March 2001 edition, the interviewer, Margaret EkuaAsabaIntsiful reveals that Rockstone (initiator of hip-life) confesses:

"I just wanted to use the language to break the barriers for cats that were into hip hop but couldn't understand English"

Hip-life is therefore a fusion of the Hip-hop music of Europe and America and the Highlife music of Africa. It is worth noting that Hip-life portrays both the culture of Africa and that of Europe and America. Hiplife musicians always try to portray their culture by using codified and pedantic language (alliteration, imagery, rhythm, lyrics and so on) in reaching out to the youth and this should be looked at critically. Hip-life emerged as a fusion of other forms of music at the close of the twentieth century. The form has features characteristic of the century. These are features which cannot be ignored because of the vehemence with which they attract attention to themselves, especially through the vehemence of expression, the extremity of body language and of the "dress code" that cannot be derived from the music of high-life.

What is significant is that the western world witnessed this development more than half a century earlier. The radical changes of all the arts that went on in Europe and America in the early twentieth century that is now referred to as "modernism" sported some salient characteristics that included the following: nothing can be taken for granted in the arts; our perception of reality is necessarily uncertain and provisional; the unparalleled complexity of modern urban life must be reflected in literary form; supposedly primitive myths can help us to grasp and order the chaos of contemporary experience; and so on. At the very surface, it appears that the paradigm shift which is similar to that which occurred in the early years of modernism in Europe and America is now occurring in Ghana in a form that may be quite different from how it manifested itself elsewhere.

\section{POETRY IN HIP-LIFE SONGS}

The term 'poetry' has been defined in several ways by literary critics and for the purpose of this work, I would like to give a brief history about what some of the critics say about poetry or the work of a poet.

According to Plato, the father of literary criticism, his work on poetry could be grouped into three aspects; the Universal Ideal Forms, inspiration and censorship and all these aspects revolve around the theory of imitation. To him, the source of composition of a poem is inspiration. He asserts that the poet is inspired by the gods and the poet in turn infects his reader with his inspiration and this is stated in the Icons: "Thus the muse inspires some and others are inspired by them until there is a whole series of the inspired".

The concept of the universal ideal forms reveals that it is the gods who own ideals and human beings only go to them to borrow or imitate these ideas. This is seen in the Republic Book X. Finally, on censorship, Plato believes that since the poet's imitation is of the third degree, that is, the imitation of an imitation, the poet does not know the nature of what is to be copied and therefore they should be censored so that they can be stopped from causing havoc. To him, when the poet imitates, he should make the youth imitate the good. This is emphasised in the Republic Book III and here he calls the poet who is capable of achieving this, the philosopher poet.

Aristotle defines poetry as "the art of imitation or representing in which the objective of imitation are men doing or experiencing something". His main objective was to differentiate between the epic, the tragic and the comic by using imitation as an instrument. Aristotle uses three principles to draw the distinctions between the three types of imitation; the manner of imitation, object of imitation and medium of imitation. The manner of imitation is simply based on form, thus the manner in which imitation is done and this is in two folds, action and narration. The objects of imitation are based on content or things imitated.

Finally, medium of imitation depends on the use of language or of music. Therefore, while the epic imitates only by means of poetry, tragedy does so by means of both poetry and music and this is stated in the Poetics chapter XXV:

'Since the poet, like a painter of animals or any other maker of likeness, i.e. an imitator, he must always imitate some one of the three aspects of things either as they were or are, or as men say they are and they ought to be"

Aristotle also talked about aestheticism. This is the theory or science of beauty which investigate how our senses appreciate our environment. He stated that the beauty of the work of the artist depends on the level of his power of artistry or skill. This piece of work of art is to give pleasure.

Sidney on the other hand defines poetry as: 
"an art of imitation, for so Aristotle termed it in the word mimesis, that is to say a representing, counterfeiting, or figuring forth - to speak metaphorically, a speaking picture; with their end to teach and delight"

In the Defence of Poesie, Sidney developed the notion of skill or art of the artist to the level of creativity which had already been introduced by Aristotle. He believes in the fact that, the poet's presentation is a combination of both imitation and the personality of the poet, what Aristotle calls "skill". Therefore, the poet can go beyond imitation to create a new world through his imagination. Like all works of art, Hip-life songs are not typically African in terms of literary style since they have western style (foreign influence) and these songs delight, teach and persuade listeners just as Horace proposed i.e. 'docere', 'delectare' and 'movere' aspects of poetry.

From the foregoing, we have seen that the definition of poetry keeps on changing depending upon the time and the personalities involved. But the most interesting and crucial point to note is that all the critics talk about how the work reflects the realities of nature or how successfully it imitates nature. One has no option than to agree with Wordsworth's definition of poetry as 'the spontaneous over flow of powerful feelings' since the Hip-life artistes express their views without fear or favour. They are therefore seen as poets who are inspired to express their views in the form of music (Hip-life).

\section{Thematic Elements}

Hip-life is a poetic and musical form of the late twentieth century, like others before it, has its peculiar characteristics and conditions which precipitate unique responses or reactions. One way of looking at these responses or reactions to the prevailing conditions is by studying the thematic elements of the works of the artistes.

Surprisingly, in spite of the large number of artistes, the themes are limited in diversity. Indeed, only very few ideas are raised in all the poetry of Hip-life. Arguably, the most dominant issue raised in the poetry of hip-life has to do with the economic problems and frustrations of the day.

The late twentieth century is a period of immense technological advancement, but the period that saw the demise of communism at the international, political as well as the expansion of the influence of Western capitalism and its associated emphasis on individuality and the importance of capital.

After attaining the status of an independent country in the middle of the century, Ghana soon began to experience a regression of her economic fortunes until the century when the government of the day declared her a Highly Indebted Poor Country. Finding themselves in such a country in the prevailing world order of extreme capitalism and globalisation, with their concomitant emphasis on the power of money, Ghanaians would naturally be affected by the extent of monetization of the economy and the general situation of joblessness and poverty that make them see all the niceties around which, unfortunately, they cannot afford.

The economic problem appears to be the major concern of Ghanaians and Hip-life artistes naturally have fertile grounds from which to grow and harvest their themes and subject matter.

Lord Kenya, the most prominent exponent of Hip-life artistry, has traces to his credit. The title of each of these productions revolves around money ("sika"). "Sika" is the title of Kenya's first CD. In the shifting perspective of the title track of this $\mathrm{CD}$, we move intermittently from the lamentation of the economically frustrated youth to the exhortation of a counsellor. It is the frustration of the youth who perceive life as "hard" because he cannot make ends meet. He attributes his plight to all kinds of factors such as witches, lack of benefactors and so on. He does all he can to get out of the situation of poverty and stagnation but to no avail. He wants to drink beer instead of "Apio" (local gin). His frustration is so intense that he thinks that death, which ends all things, will come and terminate his suffering. But the counsellor prompts him that there are good times ahead.

Another song on the "YeesomSika" (We are worshipping money) album titled "Mmobrowa" (Downtrodden) is dedicated to the downtrodden in the society. The term "Mmobrowa" refers to the economically disabled in the society who sees all the good things around them but cannot enjoy them because they do not have the means to acquire these things. Their situation is worsened by the fact that their moral uprightness is not enough to earn them high regard in the society. But this particular "Mmobrowa" will not be someone else. Rather, he is resolved to make do with what he is able to rake his own toil and sweat. He is optimistic though the current situation is not permanent; better days lie ahead.

Ene modern Ghana aye gawuta

Ghanaman, se wonnisika a

mmoborowa, obra no beyiwo ma; more than Judas

Obiaraahye ne heavy shoe nam'agye me mokas 
Today in this modern Ghana, things are hard

People of Ghana if you do not have money,

Downtrodden, life will betray you more than Judas

Everyone is wearing his heavy shoe... (Kenya:' YeesomSika')

Kontihene, another artiste, makes a similar exposition of the economically induced frustration of the times. In his "Asesa"(Change), Kontihene exposes the situation of a young man whose situation has changed from bad to worse (or is it good to bad) Life begins to move as slowly as a Methodist Hymn for him. Kontihene catalogues some of the frustrations.

Again, Rockstone'ssong titled "YabounceWo Visa" (They have bounced your visa) in which he shares his experience with us on how painful and sorrowful it is when a person is refused a visa. In spite of the frustrations people go through before they are able to acquire a visa to travel abroad, everyone still wants to travel abroad and they find all means to do so. This is attributed to the economic situation that Ghanaians find themselves. Even educated people or those trained by the government want to travel abroad to seek for greener pastures and this does not augur well for the development of this country.

So does the song "Paradise" of Akyeame's "Nkonsonkonson" (Chain Link). "Paradise" does not catalogue the frustrations of the "mmobrowa"(downtrodden) in the society. Rather, it treats them implicitly by painting a picture of the Christian paradise, showing how it is unlike anywhere on earth. Even though the focus is on "Paradise", the description of paradise is a catalogue of how it is free from the problems that are rampant in this world of ours:

\author{
"No more salary or bribery \\ No temptations to cause adultery \\ No hypocrisy \\ No false piety..."

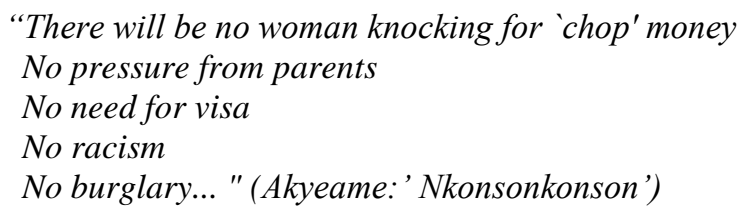

.Then, too, Paradise is depicted as a place where

In a nutshell, man's only hope for respite is in paradise. But there is a condition for entry into paradise which is, man must be cautious of whatever he does to enable him secure a place there.

On the same album, Akyeame's "Obanyansofo"(Wise person) also depicts the crisis of the young man of the century. This includes the frustrations that result from the seeming lack of progress or development in the lives of the people. This frustration is usually the source of all kinds of crime and evil and other misfortunes.

In the same vein, "Charlie Why?", also another track on "Nkonsonkonson", asks questions about the economic situation in the country which is making life unbearable for both the young and the old. The musician is surprised that Ghanaians still go for loans in spite of the fact that we have enough gold to make us rich. He describes the society as corrupt in the sense that people in authority always favour those they know. His frustration is intensified because there are no jobs and this has rendered him jobless even after completing his education. The contemporary problem is again expressed in Lord Kenya's "Obiara de ka" which reflects the current economic situation in which everyone is a debtor because none can make ends meet. But this problem of the individual is the prototype of the bigger problem of the indebtedness of the larger society.

Lord Kenya reprimands the "Driver" of the public bus on his "Sikabaa" (Rich woman) album. This is because the driver's irresponsibility is likely to lead to the loss of lives. The irresponsibility of the driver could be traced to the economic factor. Drivers desire to make as many trips as possible so as to maximize their profits. But the driver's action is not a solely self-induced one; he is encouraged by the passenger who is also in a hurry to reach his destination. Meanwhile, the policeman who is tasked to check irresponsibility on our roads is himself irresponsible. He is a corrupt officer who turns on blind eye on irresponsibility when he is financially induced to do so. Could this be a lampoon on the way the vehicle of state is managed, where the leaders, the citizens, and the judiciary are all being irresponsible in the performance of their duties?

Abrewa Nana in "Sika...W'arushie" talks about another economic theme which admonishes people to be patient and avoid rushing into disasters which are rampant. Money is the elusive "grail", the quest for which lead one through labyrinths_of hardships and disasters. 
Another major area which has been influenced by the economic situation is "love". "Sikabaa" which is the title track of Lord Kenya's first album, exposes women of the times whose only "consideration" is money. Anyone who has money to give is an acceptable companion (bed mate). Thus, she jumps from man to man. Akyeame's "To wobo" (Step Aside) also expresses the same view or concern. Here, there is an exhortation on the youth to 'chill', not to rush in the quest for success but to be patient and "take it easy".

"Aketesia" (Lady) by Kontihene also satirizes the showy young man of urban Ghana. This is the loudspeaking man who never misses any opportunity to show off his wealth to those who care to listen. In this case, the show is for the benefit of the "Aketesia" (lady) that has so attracted the love of Bra Emma as to make him boast. He is a "chef', a tycoon, who believes that the cedis, CFA, dollars and pound that he has are enough to guarantee for him the love of any lady that he professes love for. But he makes an important point when he says that the ladies knows he has a lot of money on him. It shows what actually happens in society with regards to ladies, whose only consideration is money.

Emmaa no hu se sikahye me botomu a

nawommoresresre.

Wommotumi ha me saaaranam'aniaberebere

Bro Emma, Bro Emma.

Emmaa no ha me dodo, ha me dodo

When the ladies notice that I have money in my pocket

They start to smile

They can worry to such an extent that I become aggressive

Brother Emma, Brother Emma, Brother Emma.

The ladies worry me too much, too much... (Kontihene: 'Nyankonton')

In "Ye W'adenYie" (Make your mind), Lord Kenya asserts that the persona is a different type of suitor who says his love is genuine. He persists in his pursuit of the lady in spite of all the disappointments, deceptions and ingratitude that she has caused him. He promises to be a decent lover who will provide for the needs of his lover. But it is inferred here that the lady in question is of the contemporary shock who are swayed more by economic considerations than moral ones.'

The fact that the domain of love is an infertile zone is further emphasised in "Bra Yen Tena" (Let's live together) on Akyeame's album "Nkonsonkonson". The refrain highlights the extent of corruptions in relationships when it calls on the lady to come and live with him as the wearing of someone's ring (the symbol of marriage and betrothal) is not deterrent enough to stop one from relating sexually to another. The case with which in one breath, the persona invites one and spurns another, is a demonstration of the ease with which relations are started and abrogated.

"Monica Lewinski" is the open allusion to the extra-marital relationship of no less a person than the president of the erstwhile United States of America. This is a perfect example of the extent to which morality has sunk. The truant lover who is often wandering in the wilderness of promiscuity, returns a repentant prodigal to the loved one. It is a passionate plea for restitution as a lover.

The economic considerations have come to replace genuine love. This is evident in Obrafo's song titled 'Odo' (Love) which talks about love that appears to be threatened by the general commercialisation of love. " Odo" is a lover's plea for his loved one to remain faithful in spite of the hard times. He says that even though times are hard, bad times will not last forever. Good times will come if God so wills. He is afraid to lose his lover even though his love is genuine. The fact is that one who is not financially endowed is highly disadvantaged even in the affairs of love.

Lord Kenya also buttresses this point in "Medo" (My Love) on the track album titled "YeesomSika". This is an exhortation to people to love genuinely. He says that love is a matter of the heart and therefore the need to follow one's heart in is very crucial.

Joe Frazier, another artiste, makes a similar exposition of the economic consideration that has been attached to genuine love. In his "YaaMaame" (Yaa's Mother), Frazier exposes the situation of a young man which has changed from bad to good. He is now economically sound enough to propose to his lover and to show his readiness to his mother-in-law who hitherto did not want to see him because of money. He expresses his desire to have a grand wedding ceremony and also share his wealth with his lover.

Yaamaame, ma kyeawo pen woanka hello

Kane no nawoadwa me; enneyemo o,

na me nni dough.

Joe Fraizer, bowotirinkonakaeyo 
Yaa's mother, I once greeted you but you did not say hello.

At first you were angry with me but it was not my fault

It was because I did not have money.

Here is Joe Frazier, shake your head and say yo! (Fraizer: 'YaaMaame')

OmanhenePozoh's "MedofoAdaadaaMe" (My lover has deceived me) talks about betrayal in love. Pozoh bemoans the betrayal of his lover which has disturbed him even to the point of acting on the promises and assurances given to him by his lover to make him believe that her love was genuine; she has deceived him. He attributes his inability to make ends meet to his lover's bad luck, hence the need to throw her out of his house and life.

Enneyem 'ani a, odontim 'agyaagyae me ho amawo de tuntum aye me fitaa

Me tiri mu fitaa

Me de m'akomaamawo se gyenakuta

Ede me were ahyewo mu se Yesu ne Peter

Nnsoakokoannmonmpresawoayi me ama.....

I have allowed myself for you to turn black into white

My head inside is white

I have given my heart saying that you should take it and hold on to it

In addition, I have put my trust in you just like Jesus and Peter

But the cock did not even crow three times before you betrayed me

... (OmanhenePozoh: 'Aye')

Likewise Obrafo's "Twewo ho" (Step Aside) also gives expression to the themes of ingratitude. This song also reveals the economic considerations in love. The singer gets the opportunity to show off his wealth by recounting the contributions he has made towards the success of his lady. Also he raises the issue of the tendency of people to enrich themselves wherever they find themselves. This is because the lady has taken advantage of his wealth to put up a building at Bantama (a name of a town) even though she is a house-wife.

M'hwen'abusuaamaebi aka ne nana

Me nambosuo mu anopaereberenaw'ada

Me teeyenaoresidanwoBantama

Odo ne m'danfo bi aye kanana

M'atonm'komaamaobonsamankasa

I catered for her family for even her mother

While I was suffering working in the dew of the dawn, She was still sleeping

What do I hear but that she was putting up a house in Bantama.

My loved one and my friend have colluded

I've sold my heart to Satan... (Obrafo: 'Asemsebe')

Another track on Obrafo titled "Okukuseku" emphasizes the theme of ingratitude in Hip-life songs. "Okukuseku" demonstrates the evil and treachery of a friend. He admonishes Africans to fear man rather than ghosts.

So also does Kontihene "Seniwa". "Seniwa" reveals the evils and treachery of a lover. The singer says that the blackman has evil thoughts and wizardry. His evil thoughts are compared to those of a reserve player because he does not want anyone to rise to his level.

Another rap song that depicts the lack of flourishing relationships in the society is Okomfo's song entitled "AtaaAdwoa" (Name of person). "Atta Adwoa" exposes the urbanized woman of the times whose main source of money is to exploit men. The persona is an angry young man who is claiming back everything he has bought for the lover. He ridicules women who hide behind Christianity to do all kinds of evil things.

Enorawokoo hen? Ennedaben?Ennedwoo

Wo yare? Adwuma ben nawoyo?

Mmarima ho akansie, wopueannopa 6 a gyeatenantwie.

Joe Boy! Joe Boy, n'anumupenn: enaanonaomiamiawo... 
Yesterday, where did you go? What day is today? Today is Monday.

Are you sick? What manner of work do you do?

Competing for men, when you leave the house at six o'clock, all you do is go and come.

(Okomfo: 'Kwadee')

Joe Boy! Joe Boy, from his own mouth: he confesses that some time ago, he cuddled you..

\section{Miscellaneous Themes}

Apart from all the themes discussed above, there are other miscellaneous themes that have to do with moral issues of the late twentieth century.

First and foremost, OmanhenePozoh's album titled "Woasei" (spoilt person) highlights immorality among the youth, especially young women. He focuses mainly on the kind of dresses that shamelessly expose much of their bodies to others. But he goes beyond dress to comment on other moral issues including those who are homosexuals and girls who leave home for school but end up in the rooms of 'boy friend'. He seems to suggest that the kind of dress they wear, the way the girls walk, etc. have some relation with the upsurge of cases of rape in the society.

Again, C Zar on his "Sumsumsofo" (Priest) album raises the issue of alcoholism and its effects on the youth of this country. Also, he raises the issues of the tendency to prescribe spiritual solutions for problems that are usually beyond human understanding. Thus, a person suffering from alcoholism normally is likely to consult the spiritual pastor.

Another important issue that bothers our society and the world at large is the dreadful disease, AIDS. This has been addressed by most Hip-life artistes. Okomfo on an his first album titled "Abro ne Bayie" raps on 'AIDS' (Okomfokom).In this song, the priest bemoans the terrible scourge that has taken control of Africa causing the people severe strain and stress. He tells us how the actions and inactions of people produce a long chain of victims. It is a chain that begins with one who steals away from his wife in the fashion of a "stowaway" to play an "away" love match and contracts the disease.

Another member of his family uses a razor blade used by the infected man. This person also is infected and the later has unprotected sex with his lover. He admonishes us that each and everyone should take precautions by making use of condoms. He also suggests to the government that condoms should be given freely. In a nutshell, Okomfo outlines the causes and prevention of AIDS.

Lord Kenya's song titled "Mr. P. O. P." is a funny one that ridicules the young man who would make noise when in the presence of his friends but when it is crucial for him to do productive talking, he falters miserably. Such a "guy" is said to have Plaster of Paris (P.O.P.) cast over his lips making it impossible for him to talk effectively in the presence of ladies.

Another artiste, Tic Tac advocates for personal hygiene in his song titled "Philomena Pitingeh". Tic Tac in an interview revealed that the song stressed the need for a person to keep his/her body clean from all kinds of impurities, and therefore has no sexual connotations as critics claimed.

Apart from the issues discussed above, there are also raps which do not seriously address any issues but are only meant to boast about one's capabilities and potentials in $n$ the Hip-life vein. Most of the artistes have at least one song on their albums in which they boast about themselves.

Okomfo "s song titled "MebaWonkyen" on his Kwaadee album announces his arrival on the rap scene with a boast about his capabilities and their effects. So does Obrafo in his song titled "Who Born You by Mistake", on his " Odo " album boast about himself and claims that he is an elderly person on the rap scene and hence he should be accorded respect. Again Obour's "Bo Attentenben" (Play trumpet) is a mixture of moderation and hyperbolic statements used by the artiste to announce his emergence on the Hip-life scene.

Woye lore kwan a metwawohwimhwim

Woyeabedeaamewowopimpim

Woyefufuometwawotimtim

Awo de wo a koteannyesaa a wo be himhim

Obou, me ho ye huhuhuhu.

If you are a traffic route I would pass over you at top speed.

If you are palm fruits, I would pound over you well to a thick paste.

If you are fufu, I would eat you with big morsels.

If you are feeling cold, then go and hide yourself else you would shiver.

Obuo, I evoke a lot of fear; I'm fearful. (Obour: 'Atenteben') 
It is an assertion through the use of a series of images, of what the artist is capable of doing, as a person in some assumed role does, in comparison to others in similar roles.

\section{Conclusion}

The paper has examined the lyrics of Hip-life songs and analysed them as poems from the perspectives of Plato, Aristotle and other renowned critics who are of the view that the poets are inspired to write the way they do so do Hip-life artistes. The artistes' creativity has a link with the Avant -Garde that happened in Europe and elsewhere. Hip-life is an aesthetic musical form that can be traced to the $19^{\text {th }}$ century aestheticism in Europe which was an attempt to achieve the purest form of art that is 'art for art's sake' (Pater 1839-94). In spite of the fact that most people claim they do not hear or make meaning from what the rappers say by way of content, the artistes express their views without fear or favour which is a feature of the $20^{\text {th }}$ century. Democracy is being practiced in Ghana which gives citizens the freedom to express their views in diverse ways. The future of Hiplife music continues to be bright because artistes act as the mouthpiece of the youth in the country. From the foregoing, several themes have been derived from the songs and the most crucial of them is economic hardships.

\section{Recommendations}

In recent times, corruption in Ghana has been on the ascendancy and this has to be curtailed by our leaders. Most workers in Ghana have gone on strikes, and several others are agitating to embark on strike. This has become necessary because of economic hardship that has engulfed the nation. While people continue to deal with various forms of hardships, there is massive corruption by government functionaries. A release by Franklin Kudjo (CEO of Imani Ghana) on the $31^{\text {st }}$ day of October, 2013 admonished the government to address the needs of the people else it will incur the wrath of the youth of the nation who will be compelled to demonstrate against the government. Africa leaders should be careful the way they manage the economy so as to lessen the economic hardships of its citizenry.

Notes:

1. Akeame (1999) "Nkonsonkonson" produced by Spider Web Records

2. Joe Fraizer (2001) "YaaMaame" Produced by Bandex Music Production.

3. Kontihene (2001) "Nyankonton", Produced by Agiecoat Hit Digital Music

4. Kwaadee (2001) "Okomfo ne N'atuatedom produced by Wayoosi Music and Vybetoun Record Labels.

5. Lord Kenya (1999) "YeesomSika" Produced by Mount Kenya/Goodies Records

6. Lord Kenya (1998) "Sika Baa" produced by Zap MaIIet/Slip Music.

7. OmanhenePozoh (2001) "Aye De Vol. 1" produced by OmanhenePozoh\& Kwame Ason.

8. Obour (2000) produced by Family Tree Entertainment.

9. Obrafo (2001) "Asemsebe" produced by Homebased Records.

10. Reggie Rockstone (1998) "Me Na Me Kae" produced by Kassa Records.

\section{Bibliography}

[1] Aristotle (1982) Poetics, Translated by Allan H. Gilbert in Literary Criticism: Plato to Dryden. Detroit, Wayne University Press. p. $108 \mathrm{http}: / /$ www.ghananation.com/news/

[2] Nketia, J. H. (1969) FuneralDirges of the Akan People.New York, Negro University Press.

[3] Kudjo, Franklin (2013) Peace F.M. News, Accra: Ghana.

[4] Rotimi, O.(1971)The Gods are not to Blame, Ibadan, University Press PLC.

[5] Turkson, A .A (1973) Ghanaian Wit in Songs, Accra: Ghana Publishing Corporation; 1973) pp 4-5.

[6] Sidney, P (1982) The Defence of Poesies, compiled by Alan H. Gilbert in Literary Criticism: Plato to Dryden Detroit: Wayne University Press p.414.

[7] Soyinka, W. (1963) The Loin and the Jewel, Oxford: Oxford University Press.

[8] Sutherland, E.T. (1975) The Marriage of Anansewaa, United Kingdom: Longman Group Ltd.

[9] Ward, A. C. (1970) Longman Companion to Twentieth Century Literature. United Kingdom: Longman Group Ltd.

[10] www.wwnorton.com/college/english/nael/20th century/ Sutherland E.T. (1975) 